\title{
Latex quality and yield parameters of Hevea brasiliensis (Willd. ex A. Juss.) Müll. Arg. clone PB 260 for different tapping and stimulant application frequencies
}

\author{
Yayuk Purwaningrum ${ }^{1 *}$, Yenni Asbur ${ }^{1}$, and Junaidi ${ }^{2}$ \\ ${ }^{1}$ North Sumatera Islamic University, School of Agriculture, Department of Agrotechnology, J1. Karya Wisata Gedung Johor, Medan \\ 20144, Indonesia. "Corresponding author (yayuk.purwaningrum@fp.uisu.ac.id). \\ ${ }^{2}$ Sungei Putih Research Center, Indonesian Rubber Research Institute, PO. Box 1415 Medan 20001, Indonesia.
}

Received: 7 December 2018; Accepted: 29 March 2019; doi:10.4067/S0718-58392019000300347

\begin{abstract}
Tapping and stimulant applications are an attempt to increase latex yield. A combination of stimulants with low intensity tapping systems was expected to reduce tapping costs. In addition, it was necessary to regulate the stimulant application frequency based on type and potential clone production. The objective was to determine the effect on physiological parameters and latex yield of Hevea brasiliensis (Willd. ex A. Juss.) Müll. Arg. clone PB 260 for different tapping and stimulant application frequencies. The study design was split block in randomized complete block plots with three replicates and two factors. The main plot was the tapping system consisting of four levels: quarter-spiral downward tapping (S/4 d3), quarter-spiral upward tapping ( $\mathrm{S} / 4 \mathrm{U} \mathrm{d} 3)$, half-spiral downward tapping ( $\mathrm{S} / 2 \mathrm{~d} 3)$, and half-spiral upward tapping $(\mathrm{S} / 2 \mathrm{U}$ d3). The subplots were four stimulant application frequencies consisting of ethephon $2.5 \%$ applied once every $15 \mathrm{~d}$ (ET 15d) and gas stimulant (equal to $\pm 100 \%$ ethylene) applied once every $9 \mathrm{~d}$ (ETG 9d), once every $18 \mathrm{~d}$ (ETG 18d), and once every $27 \mathrm{~d}$ (ETG 27d). The highest sucrose levels (3.62 mM) were obtained in S/2 d3 and ET/15d combination. The highest inorganic P content $(27.68 \mathrm{mM})$ was in $\mathrm{S} / 2 \mathrm{~d} 3$ and ETG/18d. The highest yield $\left(2418.53 \mathrm{~kg} \mathrm{ha}^{-1} \mathrm{yr}^{-1}\right)$ was in S/4d3 and ETG/18d. The tapping system $\mathrm{S} / 4 \mathrm{~d} 3$ and ETG/18d combination was able to increase production by $102.26 \%$ compared with the conventional tapping system (S/2 d3 and ET/15d). After the 1-yr trial, all treatments showed 0.47 to $0.54 \mathrm{mM}$ thiol content, which indicated that plants did not experience over-exploitation stress.
\end{abstract}

Key words: Ethephon, ethylene gas, inorganic phosphorus, rubber tree, sucrose, thiol.

\section{INTRODUCTION}

Latex exploitation intensity is determined by slice length, tapping frequency, and stimulant application. These three factors react to rubber tree (Hevea brasiliensis [Willd. ex A. Juss.] Müll. Arg.) clones, plant age, and seasonal variations; each clone has a different exploitation system (Boerhendhy and Amypalupy, 2011). Stimulants are commonly used to extend the latex flow period and increase yield and labor efficiency (Tistama, 2013). According to Krishnakumar et al. (2011), stimulant application can be an alternative to reduce tapping costs caused by higher labor costs and the lack of skilled workers. Herlinawati and Kuswanhadi (2013) reported that stimulant application at certain frequencies and concentrations can increase yield and maximize profits. Fahmi et al. (2015) stated that stimulant application was basically intended to reduce the tapping cost using a low intensity tapping system.

Active ethephon-based stimulants are hydrolyzed into ethylene, hydrochloric acid, and phosphoric acid in the rubber tree. Ethylene in the rubber tree tends to stimulate proton $\mathrm{H}^{+} /$sucrose pumps that activate sugar transport to latex vessel 
cells and then activate ATP-ase and P-ase proton pumps, which cause acidification of the lutoid serum and cytosolic basification (d'Auzac and Jacob, 1984). Lacote et al. (2010) reported that ethephon use can increase latex yield without disrupting plant physiological properties. However, effectiveness of the active ethephon ingredient has an indirect effect on latex yield, which can be seen within 5 to $6 \mathrm{~h}$ after its application, and yield increases only reach less than 50\% (Karyudi et al., 2006). The directly applied gas stimulant is absorbed in the latex vessels and absorbs water from the surrounding cells. This absorption increases turgor pressure and is accompanied by an increased latex flow rate (Jacob et al., 1989). Kuswanhadi et al. (2009) explain that the use of ethylene gas stimulants can increase productivity from $75 \%$ to $100 \%$ on average compared with conventional tapping systems combined with ethephon stimulants.

Stimulant application affects latex cell metabolism as indicated by various changes in the physiological parameters, including sucrose, inorganic P, thiol, and dry rubber content (DRC) levels (Obouayeba et al., 2009). Sucrose is a raw material that synthesizes cis-polyisoprene, which is needed by latex cells for latex regeneration (Priyadarshan, 2017). Inorganic phosphate levels show the intensity of metabolic activity in latex vessels (Lacote et al., 2010). Thiol levels are parameters related to antioxidants that reflect the plant's ability (active oxygen species) to prevent cell damage by free radicals (Jacob et al., 1995). Conte and Carroll (2013) state that thiols protect subcellular particle membranes; they are also anti-senescent agents.

Currently, the most widely planted clone in North Sumatra is clone PB 260. This clone is characterized by high production potential, resistance to tapping panel dryness (KAS), and strength against wind disturbances. It is also one of the latex-producing clones that were recommended for their superiority between 2010 and 2015 (Siregar et al., 2008). Until now, clone PB 260 has been used to rejuvenate and expand rubber plantations. Its yield is initially high and then continues to increase and it is resistant to leaf disease; moreover, tapping could occur after $5 \mathrm{yr}$ (Sumarmadji and Atminingsih, 2013).

The exploitation system does not usually consider concentration, stimulant application frequency, and clone properties. If this occurs over a long period of time, it triggers physiological stress on the plant due to each clone's different responses to stimulants, which can be seen from their physiological conditions. Physiological stress caused by complex interactions between clone sensitivity and exploitation intensity influences production more than the imbalance of environmental factors (Rodrigo et al., 2006). Using stimulants is one way to increase latex yield. It is also necessary to regulate stimulant application frequency based on the type and potential of clone production (Sumarmadji, 2011).

Therefore, the objective of the present study was to determine the effect on the physiological parameters and latex yield of the Hevea brasiliensis clone PB 260 for different tapping and stimulant application frequencies.

\section{MATERIALS AND METHODS}

\section{Trial location and plant material}

The field trial was carried out at two locations, Sungei Putih Research Center, Indonesian Rubber Research Institute $\left(3^{\circ} 25^{\prime} 33.8^{\prime \prime}\right.$ N, 98 $52^{\prime} 04.8^{\prime \prime}$ E; 25 m a.s.1.) and Sei Putih Estate, PT. Perkebunan Nusantara III (3²4’35.1” N, $98^{\circ} 52^{\prime} 58.5^{\prime \prime}$ E). Both sites were located in the Deli Serdang Regency, North Sumatra Province, Indonesia. The soil type of the sites is Ultisol.

Clone PB 260 (15 yr old) was used as plant material in this study, and planting space was $2.5 \mathrm{~m} \times 5 \mathrm{~m}$. Prior to the treatment, randomized sampling was performed to select 75 plants with a $65-70 \mathrm{~cm}$ girth.

\section{Experimental design}

The study design was split block in randomized complete block plots with three replicates and two factors. The main plot was the tapping system that consisted of four levels: quarter-spiral downward tapping ( $\mathrm{S} / 4 \mathrm{~d} 3$ ), quarter-spiral upward tapping ( $\mathrm{S} / 4 \mathrm{U} \mathrm{d} 3$ ), half- spiral downward tapping ( $\mathrm{S} / 2 \mathrm{~d} 3$ ), and half-spiral upward tapping (S/2U d3) (Figure 1).

The subplots were stimulant applications of liquid ethephon (2-cloro acid ethyl phosphate) $2.5 \%$ and gas stimulant (equal to $\pm 100 \%$ ethylene). The subplot stimulant application frequency treatments consisted of four levels: ethephon $2.5 \%$ applied once every $15 \mathrm{~d}$ (ET $15 \mathrm{~d}$ or 24 treatments in $1 \mathrm{yr}$ ) and gas stimulant applied once every $9 \mathrm{~d}$ (ETG 9d or 41 treatments in $1 \mathrm{yr}$ ), once every $18 \mathrm{~d}$ (ETG 18d or 20 treatments in $1 \mathrm{yr}$ ), and once every $27 \mathrm{~d}$ (ETG $27 \mathrm{~d}$ or 16 treatments in $1 \mathrm{yr}$ ). 
Figure 1. Layout of gas applicator position of each tapping system.

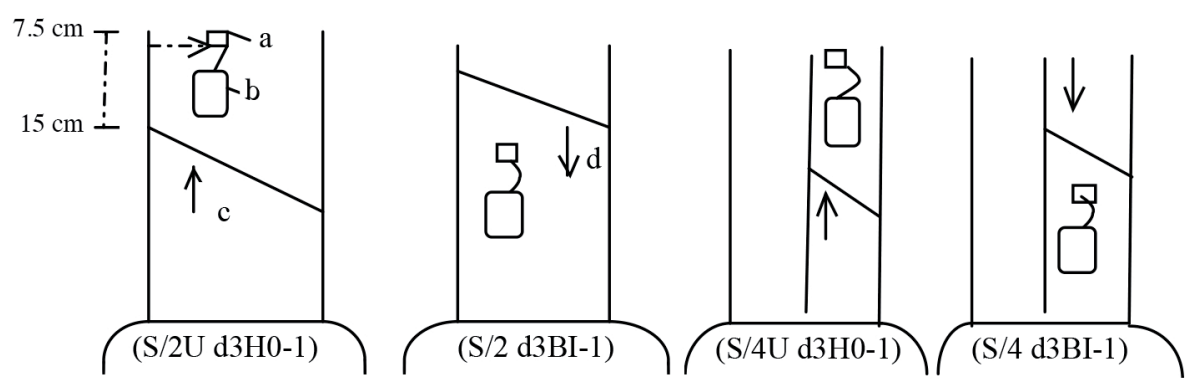

Head applicator (a), gas sac (b), upward tapping (c), downward tapping (d).

$\mathrm{S} / 2 \mathrm{U}$ : half-spiral upward tapping, S/2: half-spiral downward tapping, S/4U: quarter-spiral upward tapping, S/4: quarter-spiral downward tapping, d3: once every $3 \mathrm{~d}, \mathrm{H} 0$-1: upper virgin bark, BI-1: lower renewable bark.

\section{Stimulant application}

The liquid stimulant was applied on the virgin basal bark (B0-1) by the groove application method (Ga), while the bark application method $(\mathrm{Ba})$ was used on the virgin upper bark (H0-1). The liquid stimulant concentration was $2.5 \%$ with an application frequency of once every $15 \mathrm{~d}$ according to Junaidi et al. (2010).

The gas stimulant was also applied on B0-1 and H0-1 panels. Gas applicators were installed $15-20 \mathrm{~cm}$ above and 6.0$7.5 \mathrm{~cm}$ to the left of the tapping cut (Figure 1). The tapping activity was conducted at $3-\mathrm{d}$ intervals (d3) and gas refilling was carried out in accordance with the treatments.

\section{Yield and latex parameter measurements}

Fresh latex was collected on every tapping day. The yield (dry rubber yield) calculation was fresh yield multiplied by dry rubber content (DRC). Yield per tree per tapping $\left(\mathrm{g} \mathrm{t}^{-1} \mathrm{t}^{-1}\right)$ was total dry yield divided by the number of tapped trees and number of tapping days.

Latex parameters were observed at the Sungei Putih Research Center Laboratory. Measurements included sucrose, inorganic $\mathrm{P}$, and thiol contents. Trichloroacetic acid (TCA) serum was used for this analysis. Latex samples were collected from 135 trees of 450 trees $\mathrm{ha}^{-1}$. The serum was made from $1 \mathrm{~mL}$ latex and $9 \mathrm{~mL}$ TCA prior to the analysis. All latex parameters were measured with a Beckman DU 650 spectrophotometer (Beckman Coulter, Brea, California, USA).

\section{Sucrose content}

Latex samples were approximately $150 \mu \mathrm{L}$ and TCA $2.5 \%$ was added to complete a total volume of $500 \mu \mathrm{L}$. Then $3 \mathrm{~mL}$ anthrone reagent was added and vortexed; it was heated by soaking in boiling water for $15 \mathrm{~min}$ and cooled. The next stage was absorbance at $\lambda 627 \mathrm{~nm}$ measured by the anthrone method. Sucrose dehydration in concentrated sulfuric acid $\left(70 \% \mathrm{H}_{2} \mathrm{SO}_{4}\right)$ and heating provide furfural derivatives that react with anthrone to produce a blue color. Absorbance was measured at $\lambda 627 \mathrm{~nm}$ according to the Dische's anthrone method (Dische, 1962).

\section{Inorganic $P$ and thiol}

Inorganic $\mathrm{P}(\mathrm{Pi})$ was measured by the binding principle with ammonium molybdate and reduced by $\mathrm{FeSO}_{4}$ in an acid reaction to obtain a blue color. Absorbance measurements were taken at $\lambda 750 \mathrm{~nm}$ by the Taussky and Shorr (1953) methods.

To determine thiol, latex samples were approximately $1.5 \mathrm{~mL}$ to which TCA $2.5 \%$ was added for a total volume of 1.5 $\mathrm{mL}$; then $10 \mathrm{mM}$ DTNB $75 \mu \mathrm{L}$ plus $1.5 \mathrm{~mL}$ buffer Tris $0.5 \mathrm{M}$ were added and vortexed. The solution was kept at room temperature for $30 \mathrm{~min}$. Absorbance was read at $\lambda 412 \mathrm{~nm}$ with a spectrophotometer (Beckman) or measured from TCA serum based on the reaction principle with 5,5'-dithiobis(2-nitrobenzoic acid) (DTNB) to form yellow TNB absorbed at $\lambda 421 \mathrm{~nm}$ according to the McMullen method (McMullen, 1960). 


\section{Data analysis}

Data analysis was performed with the Statistical Analysis System (SAS) software version 9.1 (SAS Institute, Cary, North Carolina, USA). Duncan's multiple range test was applied to compare treatments at $\alpha=0.05$.

\section{RESULTS AND DISCUSSION}

\section{Agro-climatic conditions}

Agro-climatic conditions can affect the physiology, growth, and yield of rubber trees (Okoma et al, 2011; Purwaningrum et al., 2016a). A yield increase due to stimulant use is strongly influenced by the environmental conditions of the study site. Rainfall data during the study showed monthly variations. Wet months were from September to November, while dry months were from January to March; the other months were in the intermediate category (Figure 2). Oktavia and Lasminingsih (2010) state that latex yield fluctuations are notably affected by tree leaf conditions, which are closely related to monthly rainfall patterns.

Climatic factors greatly affect rubber tree phenology, including leaf-fall, new leaf formation, flowering, and fruit formation (Sayurandi et al., 2017). In North Sumatra, leaf-fall occurs from January to March during the dry period. New leaves are formed in April. In the wet months, when leaves are fully formed, production is generally high if there is no rain. This pattern also affects monthly production distribution. The highest production is generally obtained from September to December, while the lowest from January to April (Junaidi et al., 2015).

\section{Latex diagnosis and latex sucrose concentration}

Latex diagnosis determines the tree's physiological variables by the applied exploitation system (Traoré et al., 2011), including sucrose, Pi, and thiol latex. D'Auzac and Jacob (1984) and Gohet et al. (2008) indicated that stimulants affect latex cell metabolism, which are indicated by changes in latex physiological parameters, including sucrose, $\mathrm{Pi}$, and thiol levels.

Sucrose is a raw material for cis-polyisoprene synthesis, which is needed by latex cells for latex regeneration (Jacob et al., 1989). The tapping and stimulant frequency application combination significantly affected the latex sucrose levels of clone PB 260 (Table 1).

The highest sucrose levels $(3.62 \mathrm{mM})$ were obtained in the treatment $\mathrm{S} / 2 \mathrm{~d} 3$ tapping system and ET $15 \mathrm{~d}$ stimulant application frequency combination. The lowest sucrose level (1.49 mM) was in the S/4U d3 tapping system and ETG $9 \mathrm{~d}$ gas stimulant application frequency combination. This is because active ethephon-based stimulants are hydrolyzed first into ethylene gas, hydrochloric acid, and new phosphoric acid, and then hydrolyze sucrose into latex, thus leading to higher sucrose levels.

Figure 2. Monthly rainfall variation at the research site.

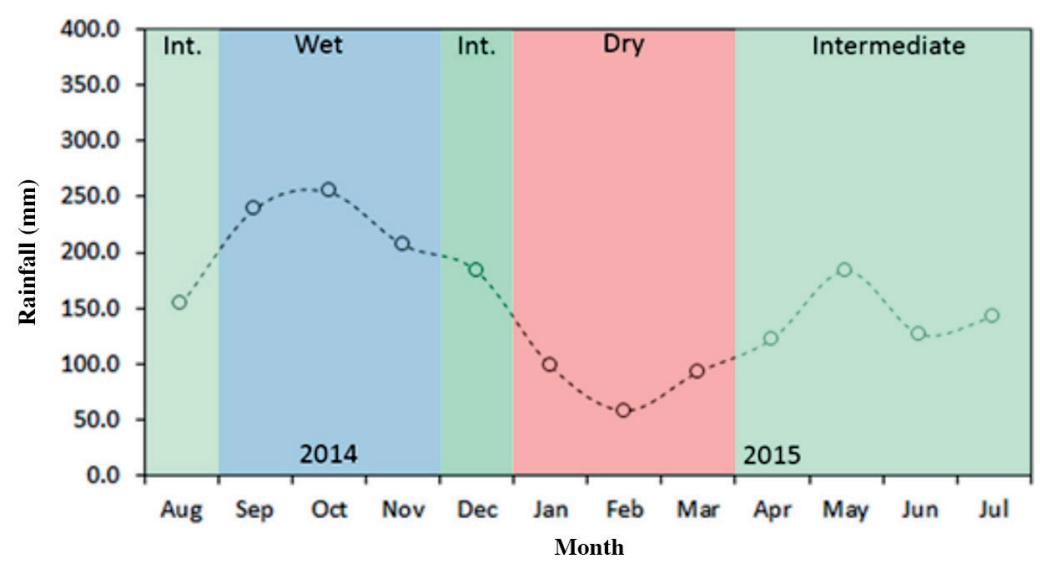


Table 1. Latex sucrose content of 15-yr-old rubber tree clone PB 260.

\begin{tabular}{llllll}
\hline & \multicolumn{5}{c}{ Stimulant frequency } \\
\cline { 2 - 4 } $\begin{array}{l}\text { Treatment } \\
\text { Tapping length }\end{array}$ & ET 15d & ETG 9d & ETG 18d & ETG 27d & Mean \\
\cline { 2 - 4 } & & & $\mathrm{mM}$ & \\
$\mathrm{S} / 2 \mathrm{~d} 3$ & $3.62 \mathrm{a}$ & $3.11 \mathrm{c}$ & $2.62 \mathrm{~d}$ & $2.40 \mathrm{e}$ & $2.69 \mathrm{a}$ \\
$\mathrm{S} / 2 \mathrm{U} \mathrm{d} 3$ & $1.66 \mathrm{gh}$ & $2.38 \mathrm{e}$ & $2.13 \mathrm{f}$ & $2.26 \mathrm{ef}$ & $2.11 \mathrm{c}$ \\
$\mathrm{S} / 4 \mathrm{~d} 3$ & $1.88 \mathrm{~g}$ & $2.81 \mathrm{~d}$ & $3.33 \mathrm{~b}$ & $2.10 \mathrm{f}$ & $2.53 \mathrm{ab}$ \\
$\mathrm{S} / 4 \mathrm{U}$ d3 & $2.18 \mathrm{ef}$ & $1.75 \mathrm{~g}$ & $1.49 \mathrm{~h}$ & $3.59 \mathrm{a}$ & $2.25 \mathrm{c}$ \\
Mean & $2.34 \mathrm{c}$ & $2.51 \mathrm{ab}$ & $2.39 \mathrm{c}$ & $2.59 \mathrm{a}$ & \\
\hline
\end{tabular}

Values in the same column and treatment group followed by different letters are significantly different according to Duncan's test $(\mathrm{P}=0.05)$.

ET 15d: Ethephon once every 15 d; ETG 9d: ethylene gas once every 9 d; ETG 18d: ethylene gas once every 18 d; ETG 27d: ethylene gas once every 27 d; S/2 d3: half-spiral downward tapping once every $3 \mathrm{~d} ; \mathrm{S} / 2 \mathrm{U} \mathrm{d} 3$ : half-spiral upward tapping once every $3 \mathrm{~d} ; \mathrm{S} / 4 \mathrm{~d} 3$ : quarterspiral downward tapping once every $3 \mathrm{~d} ; \mathrm{S} / 4 \mathrm{U}$ d3: quarter-spiral upward tapping once every $3 \mathrm{~d}$.

The direct application of gas stimulants to rubber trees as ethylene gas without going through the hydrolysis process accelerates the assimilate distribution into the latex vessel tissue. The sucrose content then decreases with gas stimulant use because of increased metabolic activity as indicated by increased Pi (Table 2). Another result of increased Pi is increased sucrose consumption in the latex regeneration process; lower sucrose levels are therefore obtained (Lacote et al., 2013). Doungmusik and Sdoodee (2012) state that the effect of gas stimulants on latex regeneration is reflected in the parameters of sucrose and Pi levels in which the sucrose concentration decreases due to increased metabolic activity as indicated by increases in the Pi concentration.

\section{Latex inorganic $P$ concentration}

Inorganic $\mathrm{P}$ is an indicator of metabolic activity; in this case, it shows the plant's ability to convert raw materials (sucrose) into rubber particles (Jacob et al., 1995). According to Sumarmadji and Tistama (2004), the optimal Pi concentration range is from 10 to $30 \mathrm{mM}$. The combination of tapping system and stimulant application frequency has a significant effect on the latex Pi levels of clone PB 260 (Table 2). The highest Pi concentration $(27.68 \mathrm{mM}$ ) was obtained in the S/2U d3 tapping system and ETG 18d gas stimulant application frequency combination, and the lowest Pi content $(21.09 \mathrm{mM})$ in the S/2U d3 tapping system and ET 15d stimulant application frequency combination. These values concur with Anggraini et al. (2017) who show high Pi concentration in clone PB 260. This is because directly applying gas stimulants to rubber trees as ethylene gas without going through the hydrolysis process activates sugar transport into latex vessel cells and increases latex Pi levels through cell physiology by maintaining high turgor pressure (Siregar and Suhendry, 2013).

Table 2. Latex inorganic P content of 15-yr-old rubber tree clone PB 260.

\begin{tabular}{llllll}
\hline \multirow{2}{*}{$\begin{array}{l}\text { Treatment } \\
\text { Tapping length }\end{array}$} & \multicolumn{4}{c}{ Stimulant frequency } \\
\cline { 2 - 4 } & ET 15d & ETG 9d & ETG 18d & ETG 27d & Mean \\
\cline { 2 - 5 } & & & mM & & \\
$\mathrm{S} / 2 \mathrm{~d} 3$ & $21.35 \mathrm{de}$ & $21.88 \mathrm{de}$ & $23.68 \mathrm{cde}$ & $23.53 \mathrm{cde}$ & $22.61 \mathrm{c}$ \\
$\mathrm{S} / 2 \mathrm{U} \mathrm{d} 3$ & $21.08 \mathrm{e}$ & $26.88 \mathrm{ab}$ & $27.68 \mathrm{a}$ & $24.00 \mathrm{~cd}$ & $25.09 \mathrm{ab}$ \\
$\mathrm{S} / 4 \mathrm{~d} 3$ & $25.22 \mathrm{abc}$ & $24.78 \mathrm{bc}$ & $27.47 \mathrm{ab}$ & $23.85 \mathrm{~cd}$ & $25.33 \mathrm{ab}$ \\
$\mathrm{S} / 4 \mathrm{U} \mathrm{d} 3$ & $23.73 \mathrm{cde}$ & $26.30 \mathrm{abc}$ & $26.83 \mathrm{ab}$ & $25.00 \mathrm{abc}$ & $25.47 \mathrm{a}$ \\
\hline Mean & $17.58 \mathrm{c}$ & $24.96 \mathrm{ab}$ & $26.42 \mathrm{a}$ & $23.96 \mathrm{ab}$ & \\
\hline
\end{tabular}

Values in the same column and treatment group followed by different letters are significantly different according to Duncan's test $(\mathrm{P}=0.05)$.

ET 15d: Ethephon once every 15 d; ETG 9d: ethylene gas once every 9 d; ETG 18d: ethylene gas once every 18 d; ETG 27d: ethylene gas once every 27 d; S/2 d3: half-spiral downward tapping once every $3 \mathrm{~d} ; \mathrm{S} / 2 \mathrm{U}$ d3: half-spiral upward tapping once every $3 \mathrm{~d} ; \mathrm{S} / 4 \mathrm{~d} 3$ : quarterspiral downward tapping once every $3 \mathrm{~d} ; \mathrm{S} / 4 \mathrm{U} \mathrm{d} 3$ : quarter-spiral upward tapping once every $3 \mathrm{~d}$. 


\section{Latex thiol concentration}

In the latex diagnosis, sucrose and Pi level measurements are more effective when combined with thiol level measurements because it reflects the ability of latex vessels to deal with aging mechanisms (Jacob et al., 1992). Thiol availability in latex is important for plants because it functions as an enzyme activator and is associated with lutoid membrane stability to prolong latex flow (Conte and Carroll, 2013).

Thiol works as an antioxidant to suppress oxidative stress due to active cell metabolism in cells; thiol status shows the plant's response to exploitation stress. Thiol levels are inversely proportional to exploitation intensity; when exploitation intensity is higher, the thiol level is lower (Jacob et al., 1995). Thiol has the ability to protect subcellular organelles and capture toxic oxygen molecules. These molecules cause latex vessel cell fatigue, which triggers tapping panel dryness.

The combination of tapping system and stimulant application frequency had nonsignificant effect on latex thiol levels (Table 3). However, the combination is still at a safe level and does not cause stress because the thiol level is still in the 0.4 to $0.5 \mathrm{mM}$ range. According to Sumarmadji and Junaidi (2008), the optimal thiol level ranges from 0.4 to $0.9 \mathrm{mM}$ in clone PB 260. Increasing the exploitation intensity affects increased thiol level, but in the case of overexploitation, thiol levels decrease (Gao et al., 2006).

\section{Latex yield}

Latex formation begins with the conversion of photosynthesis results, that is, assimilates as sucrose are converted into glucose. Saccharides as sucrose are inside the latex vessels. These compounds are precursors to form rubber particles (cis1,4 polyisoprene) (Boureau, 2013). The amount of sucrose measured in latex is the difference between the sucrose influx and sucrose used in the latex metabolism (Gohet et al., 2003).

The combination of tapping systems and stimulant application frequencies has a significant effect on the latex yield of clone PB 260 (Table 4). The highest latex yield was obtained in the S/4 d3 tapping system and ETG/18d gas stimulant

Table 3. Latex thiol content of 15-yr-old rubber tree clone PB 260.

\begin{tabular}{llllll}
\hline \multirow{2}{*}{$\begin{array}{l}\text { Treatment } \\
\text { Tapping length }\end{array}$} & \multicolumn{4}{c}{ Stimulant frequency } \\
\cline { 2 - 4 } & ET 15d & ETG 9d & ETG 18d & ETG 27d & Mean \\
\cline { 2 - 5 } & & & & & \\
S/2 d3 & 0.48 & 0.53 & 0.46 & 0.46 & 0.48 \\
S/2U d3 & 0.54 & 0.46 & 0.45 & 0.50 & 0.49 \\
S/4 d3 & 0.48 & 0.48 & 0.54 & 0.46 & 0.49 \\
S/4U d3 & 0.47 & 0.44 & 0.45 & 0.50 & 0.47 \\
\hline Mean & 0.49 & 0.48 & 0.48 & 0.48 & \\
\hline
\end{tabular}

ET 15d: Ethephon once every 15 d; ETG 9d: ethylene gas once every 9 d; ETG 18d: ethylene gas once every 18 d; ETG 27d: ethylene gas once every 27 d; S/2 d3: half-spiral downward tapping once every $3 \mathrm{~d} ; \mathrm{S} / 2 \mathrm{U}$ d3: half-spiral upward tapping once every $3 \mathrm{~d} ; \mathrm{S} / 4 \mathrm{~d} 3$ : quarterspiral downward tapping once every $3 \mathrm{~d} ; \mathrm{S} / 4 \mathrm{U} \mathrm{d} 3$ : quarter-spiral upward tapping once every $3 \mathrm{~d}$.

Table 4. Latex yield of 15-yr-old rubber tree clone PB 260.

\begin{tabular}{lccccc}
\hline \multirow{2}{*}{$\begin{array}{l}\text { Treatment } \\
\text { Tapping length }\end{array}$} & ET 15d & ETG 9d & ETG 18d & ETG 27d & Mean \\
\cline { 2 - 5 } & & & $\mathrm{kg} \mathrm{ha}^{-1} \mathrm{yr}^{-1}$ & & \\
\cline { 2 - 5 } & & & & \\
$\mathrm{S} / 2 \mathrm{~d} 3$ & $1195.75 \mathrm{k}$ & $1229.62 \mathrm{j}$ & $2271.61 \mathrm{~b}$ & $2134.97 \mathrm{~d}$ & $1707.99 \mathrm{a}$ \\
$\mathrm{S} / 2 \mathrm{U} d 3$ & $1267.03 \mathrm{i}$ & $1116.83 \mathrm{~m}$ & $2080.70 \mathrm{e}$ & $2126.09 \mathrm{~d}$ & $1647.66 \mathrm{ab}$ \\
$\mathrm{S} / 4 \mathrm{~d} 3$ & $1250.61 \mathrm{i}$ & 1189.841 & $2418.53 \mathrm{a}$ & $1598.99 \mathrm{~g}$ & $1614.49 \mathrm{ab}$ \\
$\mathrm{S} / 4 \mathrm{U} \mathrm{d} 3$ & $1295.33 \mathrm{~h}$ & $1211.30 \mathrm{k}$ & $2202.68 \mathrm{c}$ & $2059.81 \mathrm{f}$ & $1692.28 \mathrm{ab}$ \\
\hline Mean & $1243.18 \mathrm{c}$ & $1186.90 \mathrm{c}$ & $2243.38 \mathrm{a}$ & $1979.97 \mathrm{ab}$ & \\
\hline
\end{tabular}

Values in the same column and treatment group followed by different letters are significantly different according to Duncan's test $(\mathrm{P}=0.05)$.

ET 15d: Ethephon once every 15 d; ETG 9d: ethylene gas once every 9 d; ETG 18d: ethylene gas once every $18 \mathrm{~d}$; ETG 27d: ethylene gas once every $27 \mathrm{~d}$; S/2 d3: half-spiral downward tapping once every $3 \mathrm{~d}$; S/2U d3: half-spiral upward tapping once every $3 \mathrm{~d} ; \mathrm{S} / 4 \mathrm{~d} 3$ : quarterspiral downward tapping once every $3 \mathrm{~d}$; S/4U d3: quarter-spiral upward tapping once every $3 \mathrm{~d}$. 
frequency (2418.53 $\left.\mathrm{kg} \mathrm{ha}^{-1} \mathrm{yr}^{-1}\right)$ combination, and the lowest latex production was found in the $\mathrm{S} / 2 \mathrm{Ud} 3$ tapping system and ETG 9d $\left(1116.83 \mathrm{~kg} \mathrm{ha}^{-1} \mathrm{yr}^{-1}\right)$ combination. Purwaningrum et al. $(2015 ; 2016 \mathrm{a} ; 2016 \mathrm{~b})$ show that the highest latex yield occurs in the $\mathrm{S} / 4 \mathrm{~d} 3$ tapping system and gas stimulant application (ETG). Shortening the length of the tapping slices from $\mathrm{S} / 2$ to $\mathrm{S} / 4$ increases latex yield because the latex flow pressure is higher with short slices $(\mathrm{S} / 4)$; therefore, the latex flow velocity increases compared with long slices (S/2) (Sumarmadji et al., 2008).

In addition, short slice tapping provides benefits; for example, when the panel is moved, there is no full spiral slice and the relationship between the upper and lower latex vessels is unbroken; moreover, there is more efficient bark consumption, shorter tapping time, higher dry rubber content, less latex flow deviation, and relatively better tapping quality (Sumarmadji, 2011; Traoré et al., 2011). Ethylene gas in the latex vessels also absorbs water from the cells around it. This absorption increases turgor pressure, which is accompanied by an increased latex flow rate. This condition is associated with an increase in lutoid stability, which delays the latex vessel blocking process, so that latex drainage is extended and latex yield increases.

\section{CONCLUSIONS}

Stimulant application must be based on physiological conditions (inorganic $\mathrm{P}$ and sucrose levels) and plant health. The limiting factors for increased yield are inorganic $\mathrm{P}(\mathrm{Pi})$ and sucrose levels. The highest concentration of sucrose was obtained in the half-spiral downward tapping ( $\mathrm{S} / 2 \mathrm{~d} 3)$ system with stimulant application frequency consisting of liquid ethephon applied once every $15 \mathrm{~d}$ (ET 15d). The highest Pi content occurred in the combination of the S/2 d3 tapping system and gas stimulant applied once every $18 \mathrm{~d}$ (ETG 18d). The highest latex yield was in the quarter-spiral downward tapping (S/4 d3) system and ETG 18d stimulant frequency combination. The S/4 d3 tapping system combined with the ETG 18d stimulant frequency was able to increase latex yield by $102.26 \%$ compared with the conventional tapping system ( $\mathrm{S} / 2 \mathrm{~d} 3$ and ET $15 \mathrm{~d})$. After the 1-yr trial, all treatments showed a thiol concentration ( 0.40 to $0.50 \mathrm{mM})$ that indicated that plants had not experienced over-exploitation stress.

\section{ACKNOWLEDGEMENTS}

This research was funded by the Ministry of Research, Technology and Higher Education Republic of Indonesia through National Competitive Grants. The authors wish to thank the Sungai Putih Research Center and PTPN III Sungai Putih Deli Sedang, North Sumatra, which provided the research location permit and support.

\section{REFERENCES}

Anggraini, U., Rosmayati, and Damanik, R.I.M. 2017. Aktivitas superoksida dismutase dan fisiologi lateks tanaman karet (Hevea brasiliensis Muell Arg.) PB 260 dan RRIM 921 kering alur sadap parsial dengan pemberian zat pengatur tumbuh. Jurnal Agroekoteknologi FP USU 5(95):749-756.

Boerhendhy,I., and Amypalupy, K. 2011. Optimalisasi produktivitas karet melalui penggunaan bahan tanam, pemeliharaan,sistem eksploitasi, dan peremajaan tanaman. Jurnal Litbang Pertanian 30(1):2011.

Boureau, L. 2013. Metabolic engineering of isoprenoid biosynthesis. p. 2814-2851. In Ramawat, K.G., and Mérillon, J.M. (eds.) Natural products. Phytochemistry, botany and metabolism of alkaloids, phenolics and terpenes. SpringerVerlag, Berlin, Germany.

Conte, M.L., and Carroll, K.S. 2013. The chemistry of thiol oxidation and detection. In Jakob U., and Reichmann, D. (eds.) Oxidative stress and redox regulation. Springer, Dordrecht, The Netherlands.

Dische, Z.M. 1962. Carbohydrate chemistry. p. 475-514. In Whistler, R.L., and Wolfrom, M.L. (eds.) Methods in carbohydrate chemistry. Vol. 1. Academic Press, New York, USA.

D'Auzac, J., and Jacob, J.L. 1984. Physiology of the laticiferus system in Hevea. Basis and application to productivity. CompteRendu du Colloque: Exploitation and Physiology Amelioration. CRC Press, Paris, France.

Doungmusik, A., and Sdoodee, S. 2012. Enhancing the latex productivity of Hevea brasiliensis clone RRIM 600 using ethylene stimulation. Journal of Agricultural Technology 8(6):2033-2042. Available at http://www.ijat-aatsea.com (accessed 10 October 2018).

Fahmi, K., Sampoerno, and Khoiri, A.M. 2015. Pemberian stimulan etefon dengan teknik Groove application pada produksi lateks tanaman karet (Hevea brasiliensis Muell Arg.) Jurnal Online Mahasiswa 2(2). 
Gao, H., Shupe, T.F., Hse, C.Y., and Eberhardt, T.L. 2006. Antioxidant activity of extracts from the bark of Chamaecyparis lawsoniana (A. Murray) Parl. Holzforschung 60:459-462. doi:10.1515/HF.2006.073.

Gohet, E., Chantuma, P., Lacote, R., Obouayeba, S., Dian, K., Demange, A.C., et al. 2003. Latex clonal typology of Hevea brasiliensis: Physiological modelling of yield potential and clonal response to ethephon stimulation. 14 p. In IRRDB Workshop on Exploitation Technology, Kottayam. India 15-18 December. International Rubber Research and Development Board (IRRDB), Kuala Lumpur Malaysia.

Gohet, E., Scomparin, C., Cavaloc, E., Balerin, Y., Benites, G., Dumortier, F., et al. 2008. Influence of ethephon stimulation on latex physiological parameter and conquences on latex diagnosis implementation in rubber agroindustry. IRRDB Workshop: Latex Harvesting Technology. International Rubber Research and Development Board (IRRDB), Kuala Lumpur Malaysia.

Herlinawati, E., and Kuswanhadi, K. 2013. Alternatif Sistem Sadap Klon Rric 100 Mulai Buka Sadap. Indonesian Journal of Natural Rubber Research 31(2):102-109.

Jacob, J.L., Prevot, J.C., and Kekwick, R.G.O. 1989. General metabolism of Hevea brasiliensis latex (with the exception of isoprenoid anabolism). p. 101-144. In D’Auzac, J., Jacob, J.L., Chrestin, H. (eds.) Physiology of rubber tree latex: the laticiferous cell and latex, a model of cytoplasm. CRC Press, Boca Raton, Florida, USA.

Jacob, J.L., Prevot, J.C., Lacrotte, R., and Clement, A. 1992. Stress physiological ethylene effect on laticiferous system of Hevea brasiliensis. IRRDB Annual Meeting, Jakarta. 26 October-1 November. International Rubber Research and Development Board (IRRDB), Kuala Lumpur Malaysia.

Jacob, J.L., Prévôt, J.C., Lacrotte, R., Clément, A., Serres, E., et Gohet, E. 1995. Typologie clonale du fonctionnement des laticifères chez Hevea brasiliensis. Plantations, Recherche, Développement 2(5):43-49.

Junaidi, Y.R., Sembiring, V., and Siregar, T.H.S. 2015. Pengaruh perbedan letak geografi terhadap pola produksi tahunan tanaman karet. pola produksi dan pengaruhnya terhadap pasar dunia. Warta Perkaretan 34(2):127-136.

Junaidi, U., Sumarmadji, and Atmaningsih. 2010. Pengujian Sistem Eksploitasi EXPEX-315 pada klon PB 260. Jurnal Penelitian Karet 28(2):41-55.

Karyudi, K., Sumarmadji, S., and Bukit, E. 2006. Penggunaan stimulan gas etilen untuk meningkatkan produktivitas tanaman karet. National Workshop on Rubber Cultural Practices, Medan, Indonesia. 4-6 September.

Krishnakumar, R., Helen, R.L., Ambily, P.K., and Jacob, J. 2011. A modified stimulation method in Hevea brasiliensis for reducing oxidative stress. IRRDB International Rubber Conference, Thailand. 15-16 December. International Rubber Research and Development Board (IRRDB), Kuala Lumpur Malaysia.

Kuswanhadi, K., Sumarmadji, S., Karyudi, K., and Siregar, T.H.S. 2009. Optimasi produksi klon karet melalui sistem eksploitasi berdasarkan metabolisme lateks. Prosiding Lokakarya Nasional Pemuliaan tanaman karet, Batam. 4-6 August. Balai Penelitian Sungei Putih, Medan, Indonesia.

Lacote, R., Doumbia, A., Obouayeba, S., and Gohet, E. 2013. Sustainable rubber production through good latex harvesting practices: stimulation based on clonal latex functional typology and tapping panel management. IRRDB Workshop on Latex Harvesting Technology,. Binh Duong, Vietnam. 19-22 November. International Rubber Research \& Development Board (IRRDB), Kuala Lumpur, Malaysia.

Lacote, R., Gabla, O., Obouayeba, S., Eschbach, J.M., Rivano, F., Dian, K., et al. 2010. Long term effect of ethylene stimulation on the yield of rubber trees is linked to latex cell biochemistry. Field Crops Research 115:94-98.

McMullen, A.I. 1960. Thiols of low molecular weight in Hevea brasiliensis latex. Biochimica et Biophysica Acta 41:152-154.

Obouayeba, S., Soumahin, E.F., Dobo, M., Lacote, R., Gabla, O., and Doumbia, A. 2009. Agronomic performance of the clone IRCA 111 of Hevea brasiliensis under different frequencies of tapping and stimulation in South-West Cote D'Ivoire. Journal of Rubber Research 12(2):93-102.

Okoma, K.M., Dian, K., Obouayeba, S., Elabo, A.A.E., and N'guetta, A.S.P. 2011. Seasonal variation of tapping panel dryness expression in rubber tree Hevea brasiliensis Muell. Arg. in Cote d'ivoire. Agriculture and Biology Journal of North America 2(3):559-569. doi:10.5251/abjna.2011.2.3.559.569.

Oktavia, F., and Lasminingsih, M. 2010. Effect of rubber plant leaves development to production variation in IRR series clones. Indonesian Journal of Natural Rubber Research 29(2):32-40.

Priyadarshan, P.M. 2017. Biology of Hevea rubber. $2^{\text {nd }}$ ed. 251 p. doi:10.1007/978-3-319-54506-6.

Purwaningrum, Y., Asbur, Y., Hanum, C., and Siregar, T.H.S. 2016a. Exploitation system based on leaves development dynamic of clones BPM 1 in North Sumatera, Indonesia. Human Journals 4(4):261-273.

Purwaningrum, Y., Napitupulu, J.A., Hanum, C., and Siregar, T.H.S. 2016b. Pengaruh sistem eksploitasi terhadap produksi karet pada klon PB 260 effect of rubber production system exploitation against the PB 260 clones. Jurnal Pertanian Tropik 3(7):62-69.

Purwaningrum, Y., Napitupulu, J.A., Siregar, T.H.S., and Hanum, C. 2015. Histology and physiology of BPM1 clones with different exploitation systems. International Journal of Sciences: Basic and Applied Research 21(1):138-148.

Rodrigo, V.H.L., Kudaligama, K.V.V.S., and Samaraseka, R.K. 2006. Response of some Sri Lanka rubber clones to gaseous stimulation in tapping: A preliminary investigation. p. 74-87. International Natural Rubber Conference, Vietnam. 13-14 November. Ho Chi Minh, Vietnam. 
Sayurandi, S., Wirnas, D., and Woelan, S. 2017. Pengaruh dinamika gugur daun terhadap keragaman hasil lateks beberapa genotipe karet harapan hasil persilangan 1992 di pengujian plot promosi. Warta Perkaretan 36(1):1-14.

Siregar, T.H.S., Junaidi, U., Sumarmadji, Siagian, N., and Karyudi. 2008. Perkembangan Penerapan Rekomendasi Sistem Eksploitasi Tanaman Karet di Perusahaan Besar Negara. Prosiding Lokakarya Nasional Agribisnis Karet 2008 Yogyakarta. 20-21 August.

Siregar, T.H.S., and Suhendry, I. 2013. Budidaya dan Teknologi Karet. Penebar Swadaya, Jakarta, Indonesia.

Sumarmadji, S. 2011. Sistem Eksploitasi Tanaman berdasarkan Tipologi Klon (QS dan SS) dan Alternatif Sistem Eksploitasi lainnya (Expex-315 dan SS-CUT). Workshop Penggunaan Klon Unggul Baru dan Sistem Eksploitasi Tanaman Karet yang Tepat dalam Menghadapi Peningkatan Karet alam Dunia. Medan. 6-9 December.

Sumarmadji, S., and Atminingsih, A. 2013. Prinsip Dasar Penyadapan Tanaman Karet. Workshop Eksploitasi Tanaman Karet Menuju Produktivitas Tinggi dan Umur Ekonomis Optimal, Medan. 18-21 March.

Sumarmadji, S., Atminingsih, A., and Karyudi. 2008. Konsep Penyadapan Klon Slow Starter dengan Stimulan Gas Etilen dan Irisan Pendek ke Arah Atas sejak Awal Sadap. p. 1375-1386. Prosiding Lokakarya Agribisnis Karet 2008, Yogyakarta. 20-21 August. Balai Penelitian Sungei Putih, Pusat Penelitian Karet, Medan, Indonesia.

Sumarmadji, S., and Junaidi, J. 2008. Perakitan sistem sadap EXPEX-315 pada klon Quick Starter. Jurnal Penelitian Karet 26(2):153-165.

Sumarmadji, S., and Tistama, R. 2004. Deskripsi klon karet berdasarkan karakter fisiologi lateks untuk menetapkan sistem eksploitasi yang sesuai. Jurnal Penelitian Karet, 22(1):27-40.

Taussky, H.H., and Shorr, E. 1953. A micro colorimetric methods for the determination of inorganic phosphorus. Jurnal Biochemycal 202:675-685.

Tistama, R. 2013. Peran seluler etilen eksogenus terhadap peningkatan produksi lateks pada tanaman karet (Hevea brasiliensis Muell Arg).WartaPerkaretan 32(1):25-37.

Traoré, M.S., Diarrasouba, M., Okoma, K.M., Dick, K.E., Soumahin, E.F., Coulibaly, L.F., et al. 2011. Long-term effect of different annual frequencies of ethylene stimulation on rubber productivity of clone GT 1 of Hevea brasiliensis (Muell. Arg.) in South East of Cote d'Ivoire. Agriculture and Biology Journal of North America 2:1251-1260. 